\title{
EVALUATION OF ON-FARM QUICK TESTS ON SLURRIES FROM SOUTHERN CHILE DAIRY FARMS
}

\author{
Francisco Salazar S..$^{*}$, and Marianela Rosas U. ${ }^{1}$
}

Currently in Chile, there is a lack of tools to determine the real-time nutrient contribution of slurries. This study aims to evaluate three quick tests for their accuracy in estimating the total contents of N (TN), P (TP), K (TK), and ammonium-N $\left(\mathrm{N}-\mathrm{NH}_{4}{ }^{+}\right)$in dairy slurries. The quick tests included the Agros Nova Meter, Quantofix N Volumeter, and a hydrometer. While the Agros and Quantofix meters directly measure the ammonium-N content; the hydrometer indirectly estimates the total content of N, P, and K based on linear relationships with the slurry DM. Samples (73) were collected from dairy farms along Southern Chile ( $39^{\circ}$ to $44^{\circ} \mathrm{S}$ and 71 to $73^{\circ} \mathrm{W}$ ). Analyses were carried out on laboratory conditions using conventional techniques as well as using each of the quick tests. Results were subjected to straight-line regression analyses. Agros and Quantofix N-NH${ }_{4}^{+}$measurements were accurate $\left(\mathrm{P}<0.01 ; \mathrm{r}^{2}>0.80\right)$. The hydrometer estimations of TN, TP, and TK were also reliable $(\mathrm{P}<0.01)$. Best results were obtained with $\mathrm{P}\left(\mathrm{r}^{2}=0.87\right)$ and $\mathrm{N}\left(\mathrm{r}^{2}=0.79\right)$ total contents. To evaluate the kits onfarm and transfer those to dairy producers may constitute a next step towards an efficient management of organic residues in dairy farms in Chile.

Key words: Slurry, organic residue, chemical analysis, nutrients.

$I^{\text {nomine }}$ creased intensification of animal production and the concentration of livestock in specific regions imply that large quantities of slurries are produced. The slurry is a mixture of livestock feces and urine, diluted with rainfall or cleaning water, which may contain a small proportion of remains of bedding, normally used in dairy cattle buildings and feeds (Pain and Menzi, 2003). On average a $550 \mathrm{~kg}$ dairy cow excretes $19.2 \mathrm{~m}^{3}$ feces and urine $\mathrm{yr}^{-1}$, which is equivalent to $96 \mathrm{~kg} \mathrm{~N}$ cow $^{-1} \mathrm{yr}^{-1}$ (Smith and Frost, 2000). A proportion of the feces and urine is deposited during grazing; the remainder is voided in dairy buildings and collection yards during milking or housing, and requires collection. Because of the large volumes produced, manures represent an important source of organic matter and nutrients or, if it is misused, a risk of pollution (Chadwick and Chen, 2002).

The volumes and characteristics of the slurry collected depend on the dairy system. Animal manures are variable in composition, which could change depending on many factors, most notably animal live weight, diet and water intake and, for adults, whether in lactation or not (Smith and Frost, 2000). Therefore, the use of laboratory analysis is a key tool to improve management on cattle farms in order to match crop or pasture nutrients requirement to manure application rates.

${ }^{1}$ Instituto de Investigaciones Agropecuarias INIA, Carretera Panamericana Sur km 8 Norte, Osorno, Chile.

*Corresponding author (fsalazar@inia.cl).

Received: 25 January 2012.

Accepted: 21 May 2012.
In southern Chile, the reutilization of dairy slurry constitutes a common fertilizing practice nevertheless; there is a lack of information regarding the nutrient contribution and application rates when applied to farmland (Salazar et al., 2003). In this context, it is important also to take into account that not only available nutrients in slurries are important but also the organic form that could be released after mineralization, as has been shown in many laboratory and field studies (e.g. Hirzel et al., 2010).

Nowadays, laboratory analyses constitute an accurate tool to characterize the fertilizer value of slurries. Nevertheless, they seldom represent the real-time nutrient contribution because of the time delay of results and the highly variable nature of these organic residues (Van Kessel and Reeves, 2000). During the last years, additional tools have been developed as a complement to laboratory analyses (Sullivan et al., 1994). These tools include standard tables and quick tests (Chambers, 1998). Standard tables present regional average values of slurries and can be used as a baseline (Kjellerup, 1986; Salazar et al., 2007). Quick tests are easy-to-use techniques that determine with acceptable reliability, qualitative or quantitative parameters in the field during a brief period of time.

On-farm quick tests include hydrometers, nitrogen meters (Singh and Bicudo, 2005), electrical conductivity (Stevens et al., 1995), and reflectometers, differing in the nutrients they estimate and the way they assess them (Van Kessel et al., 1999). Among these techniques, hydrometers and nitrogen meters stand out for their 
accuracy, ease of use and suitability for routine on-farm analysis of dairy, poultry, and pig slurries or manures (Chambers, 1998; Van Kessel et al., 1999; Van Kessel and Reeves, 2000; Singh and Bicudo, 2005). No assessment of these complementary tools has been performed yet in Chilean farms.

The aim of this study was to evaluate a hydrometer and two nitrogen meters, Agros Nova Meter and Quantofix $\mathrm{N}$ Volumeter, for their accuracy in estimating the total contents of $\mathrm{N}, \mathrm{P}, \mathrm{K}$ and ammonium-N in dairy slurries from Southern Chile farms.

\section{MATERIALS AND METHODS}

\section{Samples}

Fresh slurry samples $(\mathrm{n}=73)$ were collected from dairy farms along Los Ríos Region ( $39^{\circ}$ to $40^{\circ} \mathrm{S} ; 71$ to $73^{\circ} \mathrm{W}$ ) and Los Lagos Region $\left(40^{\circ}\right.$ to $44^{\circ} \mathrm{S} ; 71^{\circ}$ to $\left.73^{\circ} \mathrm{W}\right)$ from May 2008 until January 2009. Representative samples were taken from slurry storage facilities (slurry lagoons or concrete tanks) after properly mixing the storage with farm equipment, or at the sampling point using a manual shaker. A 2 L sample was collected from four different points of the slurry store (North, South, East, and West) (Salazar et al., 2007) and a 1 L sub sample was stored on a high density polyethylene plastic container and transported to laboratory on a travel cooler. Upon arrival, samples were kept at $<4{ }^{\circ} \mathrm{C}$ until analysis.

\section{Laboratory analysis-conventional techniques}

Samples were analyzed at the Institute of Agricultural Research (INIA), Remehue Experimental Centre (INIA Remehue), Osorno, Chile (ISO 17.025). Determinations of DM and total contents of N (TN), P (TP), K (TK) and ammonium-N $\left(\mathrm{N}-\mathrm{NH}_{4}{ }^{+}\right)$were carried out in all samples. Dry matter was determined through oven drying at 105 ${ }^{\circ} \mathrm{C}$ to constant weight using gravimetric method. Total $\mathrm{N}$ was determined on fresh samples by Kjeldahl method using a block digestion system (Gerhardt model Vapodest 5, Königswinter, Germany) (AOAC, 1984). Total P and $\mathrm{K}$ were obtained by calcination at $550{ }^{\circ} \mathrm{C}$ and digestion with acid according to the methodology of Sadzawka et al. (2007) revised by AOAC (1984). Total $\mathrm{P}\left(\mathrm{kg} \mathrm{P}_{2} \mathrm{O}_{5}\right.$ $\mathrm{m}^{-3}$ ) was obtained by colorimetric determination using visible spectrophotometer (Perkin-Elmer model Lambda $3 \mathrm{~B}$, Phoenix, Arizona, USA). Total $\mathrm{K}\left(\mathrm{kg} \mathrm{K}_{2} \mathrm{O} \mathrm{m}{ }^{-3}\right)$ was determined by flame photometric method using an atomic absorption spectrophotometer (Perkin-Elmer model 1100B, Phoenix, Arizona, USA) and ammonium-N (kg $\mathrm{N}-\mathrm{NH}_{4}{ }^{+} \mathrm{m}^{-3}$ ) was analyzed by direct distillation and titrimetric using a distillation system (Gerhard model Vapodest 12, Königswinter, Germany) (Sadzawka et al., 2006).

\section{Laboratory analysis-quick tests}

Samples were also analyzed with the hydrometer (Qualex,
Dauntsey, Wiltshire, UK), the Agros Nova Meter (Qualex, Dauntsey, Wildshire, UK), and the Quantofix N Volumeter (Martin Sykes, Letterston, Pembrokeshire, UK) at the INIA Remehue laboratory, Osorno, Chile (ISO 17.025). Directions from manufacturers were followed closely and, for consistency, all procedures were run by the same person throughout the experiment.

The hydrometer constitutes a glass densimeter calibrated in percentage of DM. Briefly, it indirectly estimates the total contents of $\mathrm{N}, \mathrm{P}$, and $\mathrm{K}$ based on linear relationships described with the DM content of the slurry (Kjellerup, 1986). For the purposes of this study, relationships between DM and total contents of $\mathrm{N}, \mathrm{P}$, and $\mathrm{K}$ were obtained using data from conventional laboratory analyses carried out at the INIA Remehue laboratory $(\mathrm{n}=$ 157) (Table 1).

To operate the hydrometer, a $250 \mathrm{~cm}^{3}$ test tube was used. The height of the recipient must be greater than the hydrometer itself $(>25 \mathrm{~cm})$. The sample was gently homogenized and poured into the test tube up to the 250 $\mathrm{cm}^{3}$ mark. Immediately, the hydrometer was placed in the tube and allowed to stabilize. When samples were too thick, a 1-2 fold mixture with tap water was performed and readings were afterwards corrected. Readings were taken within $10 \mathrm{~s}$ to avoid reading drift due to settling of solids (Zhu et al., 2004). After every measurement, the test tube was rinsed clean.

The Agros Nova Meter and the Quantofix N Volumeter directly estimate the ammonium-N content of slurries based on the hypochlorite-oxidation method described by S. Tovborg Jensen (Kjellerup, 1986). Briefly, when ammonium ions react with hypochlorite, they are oxidized releasing gaseous molecular $\mathrm{N}\left(\mathrm{N}_{2}\right)$. The volume or pressure of this gas is directly assessed by the quick test.

The Agros Nova Meter uses pressure measurements. It constitutes a polyvinyl chloride sealed chamber attached to a manometer calibrated to read in kilograms of $\mathrm{N}-\mathrm{NH}_{4}{ }^{+}$ per cubic meter of slurry. The reagent is dry powder calcium hypochlorite $-\mathrm{Ca}(\mathrm{ClO})_{2}-65 \%$ chlorine free and utilizes sodium hydroxide $-\mathrm{NaOH}-98 \%$ concentration as a $\mathrm{pH}$ adjuster. It comes in a portable suitcase containing the nitrogen meter, the reagent and $\mathrm{pH}$ adjuster in quantities enough for 50 analyses. To operate the Agros Nova Meter, a 1:3 mixture of slurry and tap water was poured inside the chamber. A measure of reagent and half a teaspoon of $\mathrm{pH}$ adjuster were also included and the chamber was airtight sealed. The chamber was continuously shaken during 5

Table 1. Parameters and statistics of straight-line regression equations describing the local relationship between DM and total contents of nitrogen (TN), phosphorus (TP) and potassium (TK) $(n=157)$.

\begin{tabular}{lcccccc}
\hline Model & Intercept & $\mathrm{SE}_{\text {intercept }}$ & Slope & $\mathrm{SE}_{\text {slope }}$ & $\mathrm{r}^{2}$ & $\mathrm{r}$ \\
\hline $\mathrm{TN}=\mathrm{a}+\mathrm{b} \mathrm{DM}$ & $0.46^{* *}$ & 0.07 & $0.30^{* *}$ & 0.02 & 0.65 & 0.80 \\
$\mathrm{TP}=\mathrm{a}+\mathrm{b} \mathrm{DM}$ & $0.05^{* *}$ & 0.02 & $0.16^{* *}$ & 0.01 & 0.90 & 0.95 \\
$\mathrm{TK}=\mathrm{a}+\mathrm{b} \mathrm{DM}$ & $0.48^{* *}$ & 0.07 & $0.20^{* *}$ & 0.02 & 0.47 & 0.69 \\
\hline SE: standard error of the mean; ${ }^{* *} \mathrm{p}<0.01$ & & & &
\end{tabular}


min, moment in which the reading was taken (Van Kessel et al., 1999). When readings were lows $\left(<1 \mathrm{~kg} \mathrm{~N}-\mathrm{NH}_{4}^{+}\right.$ $\mathrm{m}^{-3}$ ) only slurry was utilized and results were afterwards corrected. The chamber was rinsed clean before next analysis.

Quantofix N Volumeter uses volume measurements to assess the $\mathrm{N}_{2}$ gas released. It consists of a water-filled chamber linked to a sample recipient, a reagent recipient and a metric cylinder calibrated in kilograms of $\mathrm{N}-\mathrm{NH}_{4}{ }^{+}$ per cubic meter of slurry. The reagent is liquid sodium hypochlorite $-\mathrm{NaClO}-10 \%$ chlorine free; a commonly used dairy supply for milking equipment. It comes in a portable device containing only the $\mathrm{N}$ meter. To operate the Quantofix, a 1:2 mixture of slurry and tap water was placed in the sample recipient and $150 \mathrm{~cm}^{3}$ of sodium hypochlorite was placed in the reagent recipient. After both recipients were airtight sealed and the water column was calibrated in cero, the reagent was discharged in the mixture and shook alternating between a standing time of $30 \mathrm{~s}$ and 1 or $2 \mathrm{~min}$ of stirring until completing $5 \mathrm{~min}$. Then, the reading was taken. The sample recipient was rinsed clean before next analysis.

\section{Statistical analysis}

The relationship between $\mathrm{DM}$ and $\mathrm{TN}$, TP, and TK was examined using straight line regression analysis in STATISTICA 7.0 (StatSoft, 2004) with a Type I error ( $\alpha$ error) of 0.05 (Quinn and Keough, 2002). Estimations of TN, TP, and TK with the hydrometer as well as readings of $\mathrm{N}_{-} \mathrm{NH}_{4}{ }^{+}$with the $\mathrm{N}$ meters were tested against conventional laboratory results also using straight-line regression analysis.

\section{RESULTS AND DISCUSSION}

As previously described by Piccinini and Bortone (1991), Sullivan et al. (1994), Chambers (1998), and Salazar et al. (2007), DM content was positively correlated with total contents of $\mathrm{N}(\mathrm{r}=0.80), \mathrm{P}(\mathrm{r}=0.95)$ and $\mathrm{K}(\mathrm{r}=0.69)$ (Table 1). The relationship between $\mathrm{P}$ and DM showed the best $(\mathrm{P}<0.01)$ adjustment among the three nutrients $\left(r^{2}=0.90\right)$. This may be explained by the fact that $95 \%$ of this nutrient is located in the solid phase of slurries (feces) instead of the liquid phase (urine) (Safley et al., 1984). This coefficient is higher than results obtained elsewhere for cattle slurries where it ranged from 0.69 to 0.82 (Van Kessel et al., 1999; Martínez-Suller et al., 2010). The reasonable adjustment $(P<0.01)$ obtained with $\mathrm{N}$ may respond to the highly variable nature of the nutrient itself and characteristics of dairy slurries in Southern Chile. As mentioned by Salazar et al. (2007) in Chile, there are considerable differences regarding animal feeds, management of dairy effluents and storing. The lower adjustment $(\mathrm{P}<0.01)$ with $\mathrm{K}$ may be a result of this nutrient being mostly present within the liquid phase of slurries (Chadwick and Chen, 2002). This has been previously observed by Martínez-Suller et al. (2010), who suggest electrical conductivity as the best chemical property to predict $\mathrm{K}$ contents in slurries instead of DM.

\section{Relationship between laboratory and quick test analyses}

The hydrometer. Description of the data base is shown in Table 2. There was a strong relationship $(\mathrm{P}<0.01)$ between DM readings using the hydrometer and results obtained through conventional laboratory analyses $\left(\mathrm{r}^{2}\right.$ $>0.90$ ) (Table 3 ). This has been previously highlighted by Kjellerup (1986), Piccinini and Bortone (1991), Chambers (1998) and Chadwick et al. (2004). Accurate estimations $(\mathrm{P}<0.01)$ were also obtained when relating total contents of $\mathrm{N}, \mathrm{P}$, and $\mathrm{K}$ estimated with the hydrometer and results from conventional laboratory analyses. Phosphorus estimations showed better adjustment than $\mathrm{N}$ $(\mathrm{P}<0.01)$ and the latter than $\mathrm{K}\left(\mathrm{r}^{2}=0.87 ; 0.79\right.$ and 0.29 , respectively).

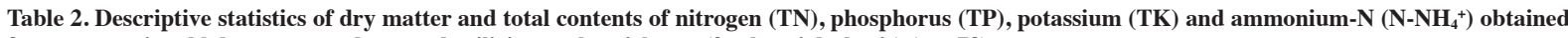
from conventional laboratory analyses and utilizing each quick test (fresh weight basis) $(n=73)$.

\begin{tabular}{|c|c|c|c|c|c|c|c|c|c|c|c|}
\hline \multirow[b]{2}{*}{ Quick test } & \multicolumn{2}{|c|}{ DM } & \multicolumn{2}{|c|}{$\mathrm{TN}$} & \multicolumn{2}{|c|}{$\mathrm{TP}$} & \multicolumn{2}{|c|}{ TK } & \multicolumn{3}{|c|}{$\mathrm{N}-\mathrm{NH}_{4}{ }^{+}$} \\
\hline & Lab & Hydr & Lab & Hydr & Lab & Hydr & $\mathrm{Lab}$ & Hydr & $\mathrm{Lab}$ & Agros & Qtfx \\
\hline & \multicolumn{2}{|c|}{$\%$} & \multicolumn{2}{|c|}{$\mathrm{kg} \mathrm{m}^{-3}$} & \multicolumn{2}{|c|}{$\mathrm{kg} \mathrm{m}^{-3}$} & \multicolumn{2}{|c|}{$\mathrm{kg} \mathrm{m}^{-3}$} & \multicolumn{3}{|c|}{$\longrightarrow \mathrm{kg} \mathrm{m}^{-3}$} \\
\hline Mean & 1.99 & 2.24 & 0.85 & 1.14 & 0.35 & 0.40 & 0.80 & 0.92 & 0.40 & 0.46 & 0.37 \\
\hline SD & 1.97 & 2.03 & 0.61 & 0.61 & 0.31 & 0.31 & 0.55 & 0.40 & 0.27 & 0.30 & 0.30 \\
\hline Min & 0.17 & 0.10 & 0.16 & 0.49 & 0.03 & 0.07 & 0.07 & 0.50 & 0.02 & 0.06 & 0.00 \\
\hline Max & 7.70 & 9.20 & 2.53 & 3.24 & 1.41 & 1.48 & 2.26 & 2.29 & 1.23 & 1.33 & 1.46 \\
\hline
\end{tabular}

Lab: Results from conventional laboratory analyses; Hydr: Results with the hydrometer; Agros: Results with the Agros Nova Meter; Qtfx: Results with the Quantofix N Volumeter.

Table 3. Parameters and statistics of straight-line regression equations describing relationships between quick tests estimations and conventional laboratory results $(n=73)$.

\begin{tabular}{|c|c|c|c|c|c|c|}
\hline Quick test & Model & Intercept & $\mathrm{SE}_{\text {interc }}$ & Slope & $\mathrm{SE}_{\text {slope }}$ & $r^{2}$ \\
\hline \multirow[t]{4}{*}{ Hydrometer } & $\mathrm{DM}_{\mathrm{Hid}}=\mathrm{a}+\mathrm{b} \mathrm{DM}_{\mathrm{Lab}}$ & $0.28^{* *}$ & 0.07 & $1.01^{* *}$ & 0.03 & 0.96 \\
\hline & $\mathrm{TN}_{\mathrm{Hid}}=\mathrm{a}+\mathrm{b} \mathrm{TN}_{\mathrm{Lab}}$ & $0.39^{* *}$ & 0.06 & $0.83^{* * *}$ & 0.05 & 0.79 \\
\hline & $\mathrm{TP}_{\mathrm{Hid}}=\mathrm{a}+\mathrm{b} \mathrm{TP}_{\mathrm{Lab}}$ & $0.07^{* *}$ & 0.02 & $0.95^{* *}$ & 0.04 & 0.87 \\
\hline & $\mathrm{TK}_{\mathrm{Hid}}=\mathrm{a}+\mathrm{b} \mathrm{TK}_{\mathrm{Lab}}$ & $0.60^{* *}$ & 0.07 & $0.40^{* *}$ & 0.07 & 0.29 \\
\hline Agros & $\mathrm{N}-\mathrm{NH}_{4}{ }^{+}{ }_{\text {Agros }}=\mathrm{a}+\mathrm{b} \mathrm{N}-\mathrm{NH}_{4}{ }_{\text {Lab }}$ & $0.06^{* *}$ & 0.03 & $0.99^{* *}$ & 0.06 & 0.82 \\
\hline Quantofix & $\mathrm{N}-\mathrm{NH}_{4}{ }^{+}$Quantofix $=\mathrm{a}+\mathrm{b} \mathrm{N}-\mathrm{NH}_{4}{ }^{+}$Lab & $-0.05^{* *}$ & 0.02 & $1.04^{* *}$ & 0.05 & 0.88 \\
\hline
\end{tabular}

TN: total nitrogen, TP: total phosphorus, TK: total potassium, SE: standard error of the mean. 
Agros and Quantofix N Meters. The Agros and Quantofix ammonium-N readings were accurate $(\mathrm{P}<$ $0.01)$ when related to the conventional laboratory results (Table 3$)$. The highest $(\mathrm{P}<0.01)$ proportion of variation accounted for was for the Quantofix $\left(\mathrm{r}^{2}=0.88\right)$, but was only marginally higher than for Agros $\left(r^{2}=0.82\right)$. This has been previously observed by Chambers (1998) and Van Kessel and Reeves (2000) and may respond to the characteristics of the reagent. While Agros uses dry powder, Quantofix utilizes liquid hypochlorite which may difficult the complete mixing between the reagent and ammonium ions in the slurry sample. It may also be a result of Agros over-predicting at lower concentrations as observed by Van Kessel et al. (1999). Since DM contents are generally low in Southern Chile dairy slurries (Salazar et al., 2007) it may be recommended to use four measures of slurry and no tap water while operating with the Agros Nova Meter.

None of the three quick tests utilized in this study took more than $10 \mathrm{~min}$ to run and they were very easy to use, which are important advantages for using on field. While the hydrometer is considered the simplest and easiest technique to use (Chambers, 1998; Van Kessel et al., 1999), Agros and nitrogen meters in general, stand out for their reliability and usefulness in technology transfer services (Singh and Bicudo, 2005).

According to a survey carried out in Southern Chile, most farmers did not know their slurry application rates (Salazar et al., 2003). This implies that no allowance is made for manure nutrients, therefore the use of this quick test could improve to match the crop or pasture requirement when using dairy slurries reducing the requirement for inorganic fertilizer and the risk of pollution to the wider environment, supporting the implementation of Good Management Practices in Chilean farms.

\section{CONCLUSIONS}

The hydrometer, Agros N Meter, and Quantofix N Volumeter were accurate $(\mathrm{P}<0.01)$ in the estimation of dry matter and total contents of $\mathrm{N}, \mathrm{P}, \mathrm{K}$ and ammonium-N in slurries from southern Chilean dairy farms. Best relationships between the hydrometer and conventional laboratory analyses were obtained for $\mathrm{P}\left(\mathrm{r}^{2}=0.87\right)$ and $\mathrm{N}$ $\left(r^{2}=0.79\right)$ compared to $K\left(r^{2}=0.29\right)$ total contents. When using the Quantofix N Volumeter and the Agros Nova Meter, good adjustments $\left(r^{2}=0.88\right.$ and 0.82 , respectively) were obtained for ammonium- $\mathrm{N}$ compared to laboratory analyses.

This study constitutes a first attempt in Chile to evaluate complementary tools for the real-time characterization of dairy slurries. The use of quick tests could be a valuable tool to transfer to dairy producers in order to achieve an efficient management of slurries on dairy farms in Chile.

\section{ACKNOWLEDGEMENTS}

Authors would like to acknowledge the Chilean Dairy Consortium, Project FIA FIC-CS-C-2004-1-P-001.

Evaluación de kits de terreno para el análisis rápido de purines en lecherías del sur de Chile. Actualmente en Chile se carece de herramientas para determinar en tiempo real el aporte de nutrientes de purines. Este estudio tuvo como objetivo evaluar la exactitud de tres kits de análisis rápido en la estimación del contenido total de $\mathrm{N}(\mathrm{TN}), \mathrm{P}(\mathrm{TP}), \mathrm{K}(\mathrm{TK})$ y $\mathrm{N}$ amoniacal $\left(\mathrm{N}^{-\mathrm{NH}_{4}}{ }^{+}\right.$) en purines de lechería. Los kits incluyeron el Agros Nova Meter, Quantofix N Volumeter y un hidrómetro. Mientras Agros y Quantofix miden directamente el contenido de $\mathrm{N}$ amoniacal; el hidrómetro estima indirectamente el contenido total de N, P y K basado en relaciones lineales con la materia seca del purín. Las muestras (73) fueron colectadas en lecherías del Sur de Chile $\left(39^{\circ}\right.$ a $44^{\circ} \mathrm{S}$ y 71 a $73^{\circ} \mathrm{O}$ ). Los análisis se realizaron en condiciones de laboratorio utilizando técnicas convencionales y cada uno de los kits. Los resultados fueron sometidos a análisis de regresión lineal. Las mediciones de $\mathrm{N}^{-\mathrm{NH}_{4}}{ }^{+}$de Agros y Quantofix fueron exactas $\left(\mathrm{P}<0,01 ; \mathrm{r}^{2}>0,80\right)$. Las estimaciones de TN, TP y TK del hidrómetro también fueron confiables $(\mathrm{P}<0,01)$. Se obtuvieron mejores resultados con $\mathrm{P}\left(\mathrm{r}^{2}=0,87\right)$ y $\mathrm{N}\left(\mathrm{r}^{2}=0,79\right)$. Evaluar los kits en terreno y transferirlos a productores podría constituir un siguiente paso hacia el manejo eficiente de residuos orgánicos en lecherías de Chile.

Palabras clave: purín, residuo orgánico, análisis químico, nutrientes.

\section{LITERATURE CITED}

AOAC. 1984. Official methods of analysis. 14 ${ }^{\text {th }}$ ed. 1141 p. In William, S. (ed.) Association of Official Analytical Chemists (AOAC), Washington DC, USA.

Chadwick, D.R., S.K.E. Brookman, J. Williams, K.A. Smith, B.J. Chambers, I.M. Scotford, and T.R. Cumby. 2004. On-farm quick tests for manure. p. 53-55. In Bittman, S., and C.G. Kowalenko (eds.) Advanced silage corn management. Pacific Field Corn Association, Agassiz, British Columbia, Canada.

Chadwick, D.R., and S. Chen. 2002. Manures. p. 57-82. In Haygarth, P.M., and S.C. Jarvis (eds.) Agriculture, hydrology and water quality. CABI Publishing, Wallingford, Connecticut, USA.

Chambers, B.J. 1998. The development of user friendly systems for on-farm estimation of the readily available nitrogen in solid manures and slurries. Final Project Report. Ministry of Agriculture, Fisheries, and Food (MAFF), London, UK.

Hirzel, J., P. Undurraga, and I. Walter. 2010. Nitrogen mineralization and released nutrients in a volcanic soil amended with poultry litter. Chilean Journal of Agricultural Research 70:113-121.

Kjellerup, V. 1986. Agros nitrogen meter for estimation ammonium nitrogen in slurry and liquid manure. p. 216-223. In Kofoed, A.D., J.H. Williams, and P. L'Hermite (eds.) Efficient land use of sludge and manure. Elsevier Applied Science Publishers, New York, USA. 
Martínez-Suller, L., G. Provolo, D. Brennan, T. Howlin, O.T. Carton, S.T.J. Lalor, and K.G. Richards. 2010. A note on the estimation of nutrient value of cattle slurry using easily determined physical and chemical parameters. Irish Journal of Agricultural and Food Research 49:93-97.

Pain, B., and H. Menzi. 2003. Glossary of terms on livestock manure management 2003. 59 p. Recycling Agricultural, Municipal and Industrial Residues in Agriculture Network (Ramiran). Swiss College of Agriculture, Zollikofen, Switzerland.

Piccinini, S., and G. Bortone. 1991. The fertilizer value of agricultural manure: simple rapid methods of assessment. Journal of Agricultural Engineering Research 49:197-208.

Quinn, G.P., and M.J. Keough. 2002. Experimental design and data analysis for biologists. 537 p. Cambridge University Press, New York, USA.

Sadzawka, A., M.A. Carrasco, R. Demanet, H. Flores, R. Grez, M.L. Mora, y A. Neaman. 2007. Métodos de análisis de tejidos vegetales. Serie Actas INIA N ${ }^{\circ} 40.139$ p. Instituto de Investigaciones Agropecuarias (INIA), Santiago, Chile.

Sadzawka, A., M.A. Carrasco, R. Grez, M.L. Mora, H. Flores, y A. Neaman. 2006. Métodos de análisis recomendados para los suelos de Chile. Serie Actas INIA N ${ }^{\circ} 34.163$ p. Instituto de Investigaciones Agropecuarias (INIA), Santiago, Chile.

Safley, L.M., J.C. Barker, and P.W. Westerman. 1984. Characteristics of fresh dairy manure. Transactions of the ASABE 27:1150-1153.

Salazar, F., J.C. Dumont, D. Chadwick, R. Saldaña, and M. Santana. 2007. Characterization of dairy slurry in southern Chile farms. Agricultura Técnica (Chile) 67:155-162.

Salazar, F.J., J.C. Dumont, M.A. Santana, B.F. Pain, D.R. Chadwick, y E. Owen. 2003. Prospección del manejo y utilización de efluentes de lecherías en el sur de Chile. Archivos de Medicina Veterinaria (Chile) 35:215-225
Singh, A., and J.R. Bicudo. 2005. Dairy manure nutrient analysis using quick tests. Environmental Technology 26:471-478.

Smith, K.A., and J.P. Frost. 2000. Nitrogen excretion by farm livestock with respect to land spreading requirements and controlling nitrogen losses to ground and surface waters. Part 1: Cattle and sheep. Bioresource Technology 71:173-181.

StatSoft. 2004. STATISTICA. Data analysis software system. Version 7. StatSoft, Tulsa, Oklahoma, USA.

Stevens, R.J., C.J. O’Bric, and O.T. Carton. 1995. Estimating nutrient content of animal slurries using electrical conductivity. Journal of Agricultural Science 125:233-238.

Sullivan, D.M., H. Bierlink, and W. Matthews. 1994. Tools for getting more value out of dairy manure. p. 55. In $26^{\text {th }}$ Annual Dairy Producers Short Course, Clearbrook. 8-9 February 1994. British Columbia Ministry of Agriculture, Fisheries and Food, Chilliwack, British Columbia, Canada.

Van Kessel, J.S., and J.B. Reeves III. 2000. On-farm quick tests for estimating nitrogen in dairy manure. Journal of Dairy Science 83:1837-1844.

Van Kessel, J.S., R.B. Thompson, and J.B. Reeves III. 1999. Rapid on-farm analysis of manure nutrients using quick tests. Journal of Production Agriculture 12:215-224.

Zhu, J., P.M. Ndegwa, and Z. Zhang. 2004. Manure sampling procedures and nutrient estimation by the hydrometer method for gestation pigs. Bioresource Technology 92:243-250. 